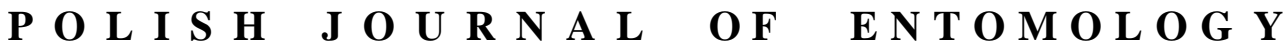

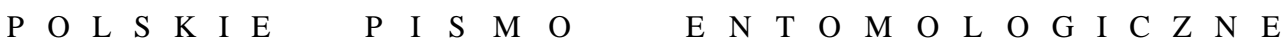

VOL. 85: $365-376$

Lublin

31 December 2016

DOI: $10.1515 /$ pjen-2016-0021

\section{Systematics and Faunistics of Neotropical Olethreutini, 3: Omiostola MEYRICK, 1922 (Lepidoptera: Tortricidae)}

\author{
JÓZEF RAZOWSKI $^{1 *}$, VITOR O. BECKER ${ }^{2}$ \\ ${ }^{1}$ Institute of Systematics and Evolution of Animals, Polish Academy of Sciences, \\ 31-016 Kraków, Sławkowska 17, Poland \\ ${ }^{2}$ Reserve Serra Bonita, P.O. Box 01, 45880 Camacan BA, Brazil
}

\begin{abstract}
Seven species of Omiostola are recorded from Brazil, Ecuador and Cuba, four of which (O. longimacula, O. paragerda, O. manca, O. macella) are described as new. An alphabetical list of the known species of the genus is provided. $O$. macrotrachela is synonymized with $O$. hemeropis. Episimus melanaspis and E. varablancana are transferred to Omiostola.
\end{abstract}

KEY WORDS: Lepidoptera, Tortricidae, Omiostola, Neotropic, new species, new synonym, new combinations.

\section{INTRODUCTION}

Omiostola MEYRICK, 1922 is an exclusively New World Olethreutini genus consisting of 15 described species, known chiefly from South America. However, several new undescribed species have recently been discovered in Central America.

Omiostola is closely related to another tropical genus, Episimus WALSINGHAM, 1892, recorded from the Neotropical (main bulk) and Afrotropical (two species) regions. Neotropical Episimus was revised by RAZOWSKI \& BROWN (2010) and characterized chiefly as having "a variably-developed hair-pencil extending from the lower edge of the tegula laterally along the thorax beneath the wings". Omiostola lacks the hair-pencil (more correctly, a scale pencil). The tegulae of Omiostola are greatly lengthened, extending nearly to the end of the thorax.

\footnotetext{
*Corresponding author: Razowski@isez.pan.krakow.pl
} 
According to the original description and illustration by CLARKE (1958), Omiostola has stalked forewing veins R4-R5. This character state is almost constant (also found in O. adamantea MEYRICK, 1922, O. macella sp. n., O. paragerda sp. n.), but R4-R5 are occasionally separated at the median cell, as in $O$. delta RAZOWSKI \& WOJTUSIAK 2008, O. hemeropis RAZOWSKI \& WoJTUSiaK 2008 and O. longimacula sp. n., a state also found in Episimus. The most frequent forewing marking in Omiostola is a dark dorsobasal blotch, which may be divided into parts or more or less reduced. That of Episimus more closely resembles the general olethreutine markings but is also variable.

The two genera have similar genitalia. In Episimus males the genitalia have a simple, usually slender uncus, whereas in Omiostola the uncus has a more or less long, slender terminal process. Beyond the sacculus angle, Episimus has a variably-developed ventral lobe that in Omiostola is weakly developed or completely reduced, occasionally even lacking spines. The differences in the female genitalia are smaller still. A molecular study of these genera may shed light on their reciprocal relation.

The infrageneric system of Omiostola is certainly imperfect. The presence of the subterminal fascia (in $O$. hemeropis) is presumably the most generalized marking in this genus. This species also has the most primitive male genitalia, in which the ventral lobe of the sacculus and its group of spines (setae) are absent. In O. hemeropis, however, the pattern is represented only by the medioanterior part of the dorsobasal blotch. A distinct dorsobasal blotch is present in several species (e.g. O. delta). In other species, various parts of the blotch are preserved: in $O$. macella, $O$. manca sp. n. and a few other species the proximal part of the delta-shaped blotch is preserved and accompanied by a strong suffusion of the whole dorsum; in $O$. varablancana a fascia extends from the wing base along vein $\mathrm{A} 1+\mathrm{A} 2$; in $O$. gerda BusCK, 1912 and O. paragerda there is complete reduction of the blotch. In all these species the male genitalia have a ventral lobe of the sacculus and the saccular spines.

The shape of the uncus is not correlated with the markings. As the most generalized character state, we treat it with uniformly broad basal part. In $O$. varablancana and a few undescribed Costa Rican species, the uncus is basally constricted; in others the uncus is long and slender $(O$. macella $)$, or its terminal processes are long (O. splendissima); the forewing markings of the latter are unique, consisting of several parts of transformed tortricine markings.

\section{Acknowledgements}

The authors thank Mr Artur CZEKAJ, Kraków, for taking the photographs and arranging the plates. 


\section{MATERIALS}

The paper is based on specimens collected by the second author in Brazil and Ecuador. The holotypes of the new species are deposited in the BECKER Collection (BC) and will eventually be transferred to a major Brazilian museum. The numbers cited after the label data are the entry numbers to the specimens in the register book of V.O. BECKER.

\section{Abbreviations}

BC - BECKER Collection; GS - Genitalia slide; WZ - Witold ZAJDA; NHML - Natural History Museum London; USNM - National Museum of Natural History.

\section{Omiostola MEYRICK, 1922}

Omiostola MEYRICK, 1922, Exot. Microlepid., 2: 519; Type-species: Omiostola alphitopa MEYRICK, 1922, by original designation.

Alphabetical list of species

(known sex, country of origin, and references given)

adamantea MEYRICK, 1922: 520 (Omiostola), male, Brazil; ClARKE 1958: 560 albidobrunnea RAZOWSKI \& WOJTUSIAK, 2010: 122, (Omiostola), male, Peru alphitopa MEYRICK, 1922: 519 (Omiostola), male, Brazil; CLARKE 1958: 560 basiramula RAZOWSKI \& WOJTUSIAK, 2011: 114 (Omiostola), male, female, Colombia brunneochroma RAZOWSKI \& WOJTUSIAK, 2011: 114 (Omiostola), male, Ecuador delta RAZOWSKI \& WOJTUSIAK, 2008: 54 (Omiostola), male, Ecuador detosema RAZOWSKI \& WOJTUSIAK, 2011: 114 (Omiostola), female, Colombia gerda BUSCK, 1912: 227 (Olethreutes), female, French Guiana hemeropis DoGNIN, 1912: 49 (Olethreutes), male, Colombia

= macrotrachela MEYRICK, 1922: 519 (Omiostola), male, Colombia; CLARKE 1958: 560 melanaspis (MEYRICK, 1927): 337 (Episimus), Colombia; ClARKE 1958: 336 paradelta RAZOWSKI \& WOJTUSIAK, 2010: 121 (Omiostola), male, Peru splendissima RAZOWSKI \& WOJTUSIAK, 2008: 540 (Omiostola), male, Ecuador triangulifera RAZOWSKI \& WOJTUSIAK, 2008: 452 (Omiostola), male, Ecuador varablancana RAZOWSKI \& BROWN, 2010, (Episimus), male and female, Costa Rica youngi RAZOWSKI, 1999: 332 (Omiostola), male, Ecuador. 


\section{RESULTS}

\section{Omiostola hemeropis (DOGNIN, 1912)}

(Figs 1,9)

\section{Material examined}

One male from Ecuador (Carchi, Maldonado 2200 m, 9-11. I. 1993; BC 105304).

\section{Remarks}

Omiostola macrotrachela MEYRICK, 1922, (Exotic Microlep., 2: 519), syn. n., is a synonym of Olethreutes hemeropis DognIN, 1912 (Hétér. Nouveaux d'Amérique du Sud, 6(6): 49). Both were described from males from San Antonio, Colombia. The lectotype (NHML) of the former was illustrated by CLARKE (1958), and the figure was compared with the type of hemeropis (USNM).

Our specimen (Fig. 1) was collected in the Province of Carchi, Ecuador, at a similar altitude as $O$. macrotrachela.

\section{Omiostola adamantea MEYRICK, 1922}

(Figs 2, 7, 10, 11)

\section{Description}

Examined specimens. Wingspan $23 \mathrm{~mm}$. Head and thorax creamish, head with slight yellowish admixture, thorax mixed greyish, labial palpus brown. Forewing ground colour pale ferruginous cream; posterior halves of costa and dorsum more rust; basal half of costa greyish brown, dorsal half of dorsal area brownish; median area between these marginal parts and base cream dotted. Costa strigulae indistinct, creamish; divisions rust; ocellar area with series of dark brown spots extending towards costa where small. Tornal area suffused brown grey; terminal area more rust. Cilia blackish brown, creamer at apex of wing, whitish at tornus. Hindwing brownish grey, cilia paler.

Variation. Female wing span $25 \mathrm{~mm}$. Ground colour suffused rust; tornus mixed grey; remnants of dorsobasal blotch rust brown.

Male genitalia (Fig. 2). Uncus broad basally, tapering to beyond middle with slender terminal arms; socius ovoid; basal part of sacculus curved outwards; neck of valva broad; ventral incision shallow; cucullus convex caudally; aedeagus broad proximally, tapering ventroterminally. 

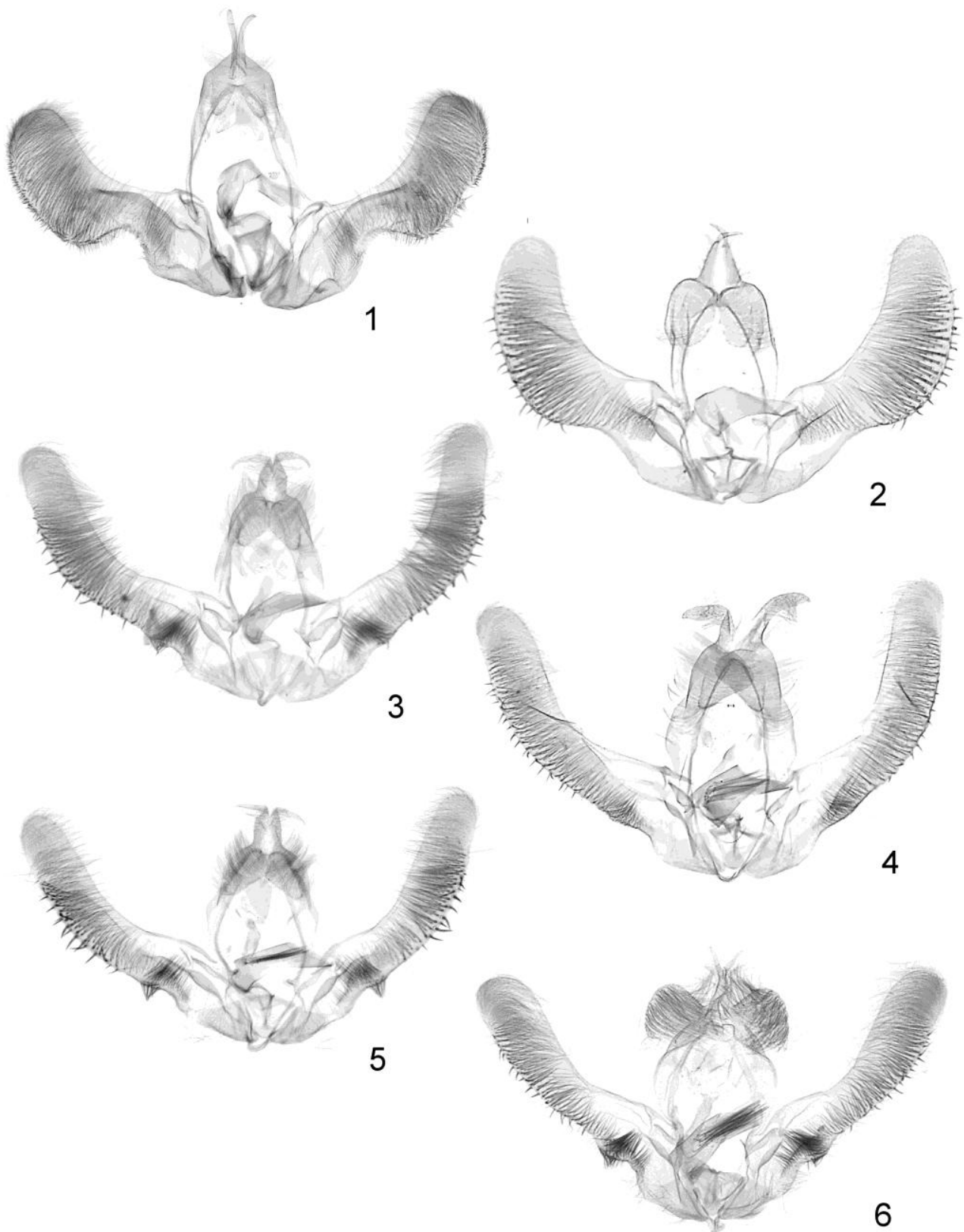

Figs 1-6. Male genitalia: 1 - Omiostola hemeropis, Maldonado, Carchi, Ecuador; 2 - O. adamantea, Bahia, Brazil; 3 - O. longimacula sp. n., holotype; 4 - O. manca sp. n., holotype; 6 - O. macella sp. n., holotype. 

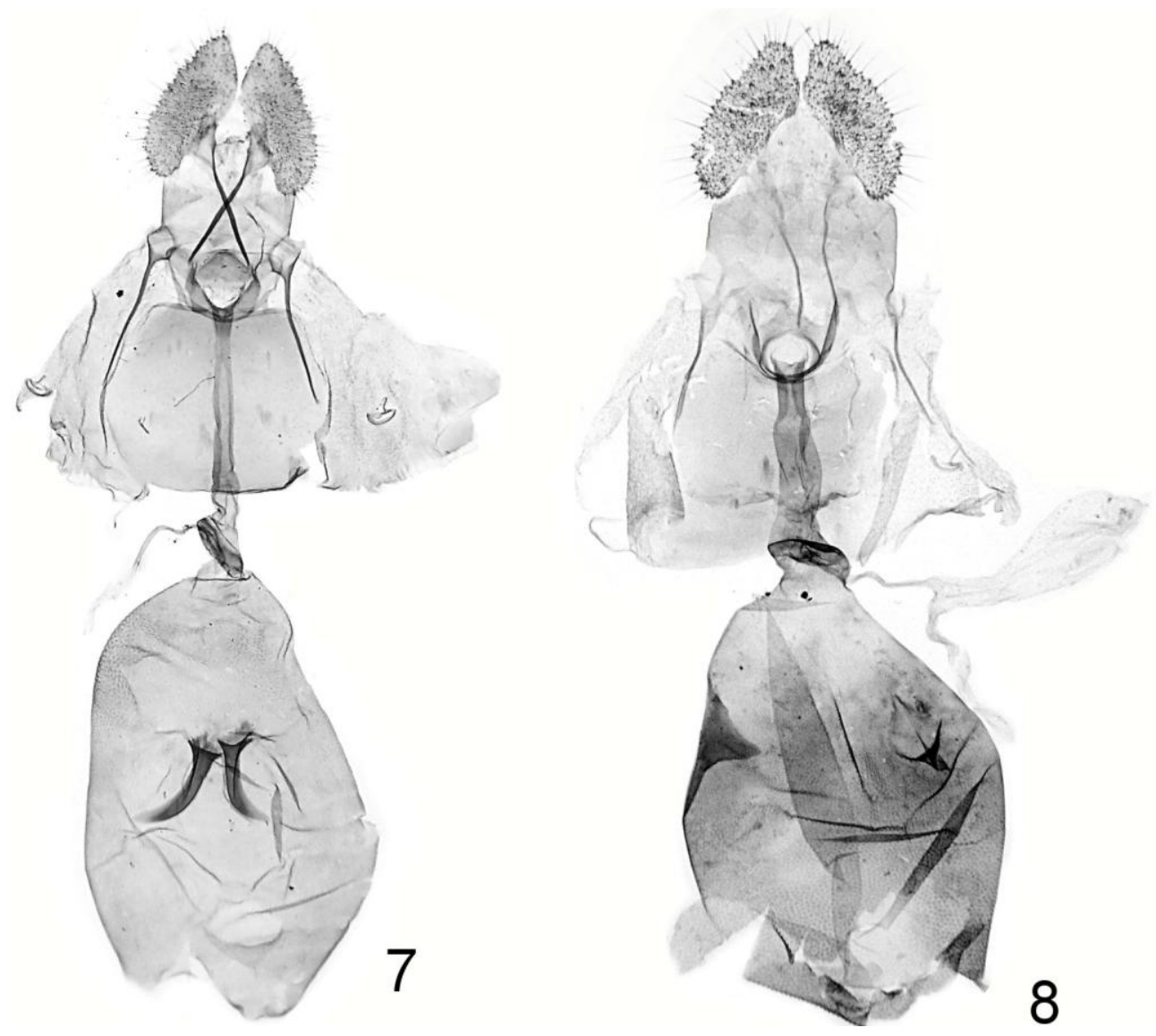

Figs 7, 8. Female genitalia: 7 - Omiostola adamantea, Bahia, Brazil; 8 -O paragerda sp. n., paratype.

Female genitalia (Fig. 7). Sterigma rounded with broad anteostial half extending in middle posteriorly; sclerite of antrum weak, short; cingulum slender, oblique; signa long with small basal parts.

\section{Material examined}

Two males and two females: "Brasil: BA[hia], Jequie 600-750 m, 11-22. XI. 1985, V.O. BECKER Col.; Col. BECKER 105924” GS 754 WZ (male), 755 WZ (female). 

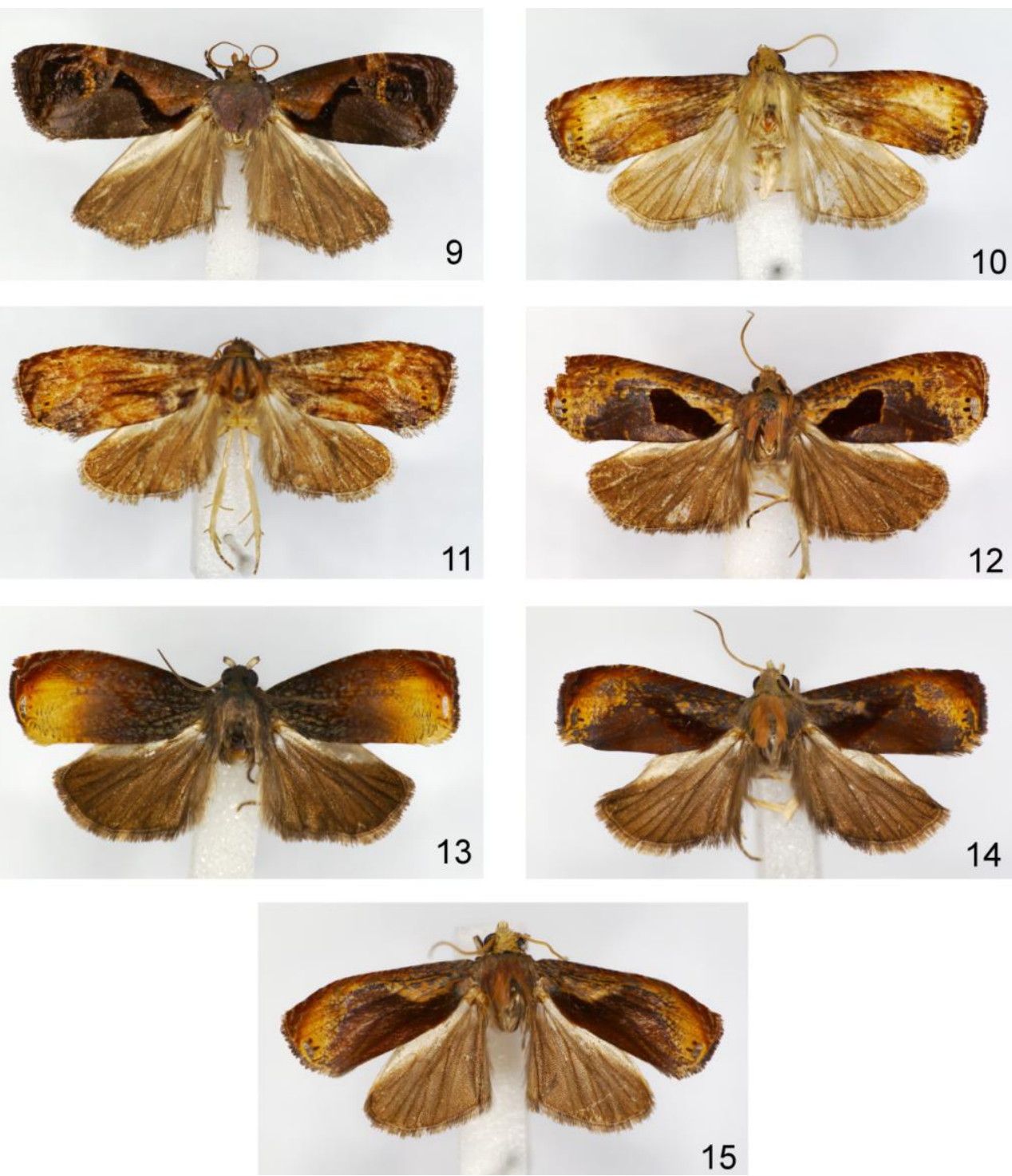

Figs 9-15. Adults: 9 - Omiostola hemeropis, Maldonado, Carchi, Ecuador; 10 - O. adamantea, male, Bahia, Brazil; 11 - O. adamantea, female, Bahia, Brazil; 12 - O. longimacula sp. n., holotype; 13 - O. paragerda sp. n., holotype; 14 - O. manca sp. n., holotype; 15 - O. macella sp. n., holotype. 


\section{Remarks}

CLARKE (1958) illustrated the male lectotype of $O$. adamantea (from Manaos, Brazil) but the genitalia cannot be accurately compared with those of our specimens because of their slight deformations (insufficiently pressed cover slip) in the lectotype. The specimens also differ in colouration, hence the above descriptions. The female genitalia of this species were previously unknown.

\section{Omiostola longimacula sp. n.}

(Figs 3, 12)

\section{Diagnosis}

In facies, $O$. longimacula is similar to $O$. hemeropis but is distinguished by a broad, oblique dorsobasal blotch and the lack of a fascia extending from the tornus. This species differs from O. triangulifera in the shape of the dorsobasal blotch (broad, triangular in the latter), the longer basal part of the uncus and the broader aedeagus.

\section{Description}

Wingspan $22 \mathrm{~mm}$. Head and thorax brownish, thorax tinged grey medially, tegula similarly so distally. Forewing weakly expanding posteriorly; termen indistinctly concave medially. Ground colour brownish cream suffused rust and spotted grey in costal area with diffuse rust in posterior and apical parts of wing; dorsum dark grey. Costal strigulae brownish cream; divisions rust; ocellus with three dark brown spots and posterior refractive line. Dorsobasal blotch elongate, rounded terminally, purple brown, finely edged creamish; arched rust line representing subapical fascia. Cilia rust brown, creamish in tornal third. Hindwing dark brown; cilia similar.

Male genitalia (Fig. 3). Basal half of uncus broad, posterior parts in form of two slender arms; socius broad, oval; sacculus weakly angulate; ventral incision of valva weak; ventral lobe of sacculus small, area above it spined; cucullus long; aedeagus short, extending ventroposteriorly.

Female unknown.

Holotype male: "Ecuador: Tung[urahua], Rio Verde 1600 m, 26. XII. 1992, V. O. BECKER Col; Col. BECKER 104070"; GS 765 WZ.

\section{Etymology}

The name refers to the shape of the dorsobasal forewing blotch; Latin: longus - long, macula - a blotch. 


\section{Omiostola paragerda sp. n.}

(Figs 4, 8, 13)

\section{Diagnosis}

In the facies, $O$. paragerda is similar to $O$. gerda but $O$. paragerda can be distinguished by the large blades of the signum and the well sclerotized cingulum.

\section{Description}

Wingspan $22 \mathrm{~mm}$. Head and proximal third of thorax dark brown, remaining parts of latter brownish. Forewing expanding posteriorly; costal half of termen not oblique. Ground colour yellow cream suffused pink brown to middle, dark brown in basal third, densely refractive dotted; costa and apical area more rust. Costal strigulae indistinct, divisions rust brown; posterior area of wing from tornus to before 3/4 of costa cream tinged rust towards costa posteriorly where marked by fine brown lines; ocellus with three spots and broad posterior line. Subterminal fascia slender, rust. Cilia brown, cream in tornal fourth. Hindwing dark brown; cilia slightly paler.

Male genitalia (Fig. 3). Basal part of uncus broad, short, posterior arms broad; socius subtriangular, rounded, broad; sacculus fairly short, angulate; ventral lobe of sacculus indistinct, hairy and spined; aedeagus short, broad; cornuti long.

Female genitalia (Fig. 8). Sterigma broad, rounded proximally, expanding in middle posteriorly; sclerite of antrum well developed; cingulum slender; signa large with strong blades.

\section{Type material}

Holotype male: "Brasil: M[ato]G[rosso] 800 m, Chapada dos Guimaraes, 20. XI. 1994, V.O. BECKER Col; Col. BECKER 94164”; GS 758 WZ. Paratype female, identical label; GS 757 WZ.

\section{Etymology}

The specific epithet refers to the external similarity of this species to $O$. gerda; Latin: paranear.

Omiostola hemeropis RAZOWSKI \& WOJTUSIAK, 2008

\section{Material examined}

Three specimens from Ecuador (Carchi, Maldonado 2200 m, 9-11. I. 1993; GS 105303). 


\section{Remarks}

O. delta was described from same Province and was collected at similar altitude (2000 $\mathrm{m}$ in the Golodrinas Forest Reserve). Our specimens differ from the type in having a more elongate, posteriorly rounded, dorsobasal blotch and somewhat longer aedeagus and socii.

\section{Omiostola manca sp. n.}

(Figs 5, 14)

\section{Diagnosis}

$O$. manca is related to $O$. triangulifera but $O$. manca is distinguished chiefly by the slender dorsobasal blotch and the strongly reduced pale area of the forewing ground colour. The genital differences between these species are slight: $O$. manca has a deeper ventral incision of the sacculus and a broader aedeagus.

\section{Description}

Wingspan $17 \mathrm{~mm}$. Head and collar cream grey, end of labial palpus and tegula darker, greyer; median part of thorax rust. Forewing termen straight to beyond middle. Ground colour cream tinged ferruginous preserved in subcostal and tornosubterminal area of wing, densely strigulated leaden grey in basal half of wing weakly so in subterminal surface; costa and apex rust; costal strigulae indistinct, mostly cream, divisions brown. Dorsum dark brown, tinged grey posteriorly. Markings in form of slender, purple brown dorsobasal blotch. Cilia blackish brown, rust at apex, creamish at tornus. Hindwing and cilia brown.

Male genitalia (Fig. 5). Anterior part of uncus uniformly broad; posterior arms slender; socius broad slightly tapering ventrad; angle of sacculus weak; ventral lobe of cucullus with spines; aedeagus moderately short and broad; cornuti long.

Female unknown.

\section{Material examined}

Holotype male: "Brasil: R[io de]J[aneiro 800 m, Nova Friburgo, 22. I. 1993, V.O. BECKER Col; Col. BECKER 86032”; GS 758 WZ. Paratype one identically labelled male.

\section{Etymology}

The name refers to the reduced area of pale forewing ground colour; Latin: manca incomplete. 


\section{Omiostola macella sp. $\mathbf{n}$.}

(Figs 6, 15)

\section{Diagnosis}

In facies, O. macella somewhat resembles $O$. alphitopa but $O$. macella has a welldeveloped dorsobasal blotch on the forewing and a slender, terminally bifurcate uncus.

\section{Description}

Wingspan $22 \mathrm{~mm}$. Head greyish white, labial palpus more brown, frons white; thorax rust brown, dark brown proximally, base of tegula greyish. Forewing termen mostly straight. Ground colour cream in basal area spotted dark grey in distal half of wing tinged rust posteriorly, weakly spotted only at markings edges. Costa and apex rust, in basal third rust brown; costal strigulae indistinct, creamish; divisions rust; ocellar area with two black spots and dark brown row of spots posteriorly. Dorsum rust brown, dark brown anteriorly (diffuse remnants of dorsobasal blotch) and at tornus accompanied by brownish grey strong suffusion inside posterior half of median cell. Cilia rust brown, brown basally and at tornus. Hindwing brown, cilia paler.

Male genitalia (Fig. 6). Uncus slender, gradually tapering towards middle, then bifurcate; socius large, broad, rounded; sacculus angulate; ventral incision of valva indistinct; ventral lobe of sacculus weak, broad, densely spined; costal part of cucullus broadening terminad; aedeagus moderately broad; cornuti long.

Female unknown.

\section{Material examined}

Holotype male: “Cuba: Pinar Rio, Sierra Rosario 400 m, 5-15. VI. 1990, V.O. BECKER Col; Col. BECKER 71536”; GS 1265 WZ.

\section{Etymology}

The specific name refers to the shape of the uncus; Latin: macella - lean.

\section{REFERENCES}

Busck A. 1912. Descriptions of new genera and species of Microlepidoptera from Panama. Smithsonian Miscellaneous Collections, 59(4): 205-230.

Clarke J.F.G. 1958. Catalogue of the type specimens of Microlepidoptera in the British Museum (Natural History) described by Edward MEYRICK. Vol. 3. Trustees of the British Museum, London.

Dognin P. 1912. Hétérocères nouveaux de l'Amérique du Sud. Fascicule 6. Imprimerie Oberthur, Rennes. 
MEYRICK E. 1922. Exotic Microlepidoptera, volume 2. Taylor and Francis, London.

MEYRICK E. 1927. Exotic Microlepidoptera, volume 3. Taylor and Francis, London.

RAZOWSKI J. 1999. Tortricidae (Lepidoptera) from Ecuador. Acta zoologica cracoviensia, 42(2): 321-342.

RAZOWSKI J., BROWN J.W. 2010. New species, new combinations, and new synonymies in Neotropical Episimus WALSINGHAM, 1982 (Lepidoptera: Tortricidae: Olethreutinae). Acta zoologica cracoviensia, 51B: $83-144$.

RAZOWSKI J., WoJTUSIAK J. 2008. Tortricidae from the mountains of Ecuador. Part III: Western Cordillera (Insecta: Lepidoptera). Genus, 19(3): 497-575.

RAZOWSKI J., WoJTUSIAK J. 2010. Tortricidae (Lepidoptera) from Peru. Acta zoologica cracoviensia, 51B: 73-159.

RAZOWSKI J., WoJTUSIAK J. 2011. Tortricidae (Lepidoptera) from Colombia. Acta zoologica cracoviensia, 51B: $103-128$.

Received: 27 May 2016

Accepted: 19 May 2016 